\author{
Yuriy Harust, \\ Dr.Sc., Associate Professor, Sumy State University, Ukraine \\ Vadym Melnyk, \\ Ph.D., Sumy State University, Ukraine \\ Maksym Palienko, \\ Ph.D., University of Insurbia, Italy \\ Lesya Prasol, \\ Entrepreneur, China
}

\title{
ECONOMIC SECURITY OF THE COUNTRY: MARKETING, INSTITUTIONAL AND POLITICAL DETERMINANTS
}

\begin{abstract}
The aim of the paper was analysing of the main indicators which influence on the country's economic security. The authors allocated the main approaches to define economic security. Traditionally the economic security was analysed as a range of economic parameters which are not considering the institutional and marketing parameters. The authors highlighted, the different types of combinations of marketing, political and institutional indicators could influence on the level of the country's security level with different power. On this basis, the key factors which influenced on the level of the economic security were identified. All indicators were combined in three groups: marketing, political and institutional. To the political indicators, the parameters as follows were included: violence/terrorism; voice and accountability rating; rule of law; control of corruption. The marketing group of indicators contained the parameter - the country's brand. The institutional group involved: adjusted net national income per capita; agricultural raw materials exports; agriculture, value-added; external balance on goods and services; food exports; food imports; foreign direct investment, nett inflows; GDP growth; wage and salaried workers, total; GDP per capita growth; industry, value-added; total natural resources rents; trade. Thus, in the paper, the authors checked the hypothesis as follows: the existence of the statistically significant relationship between marketing, political and institutional parameters and level of economic security. The informational basis for analyses was dataset from the: World Government Indicators, Future Brand, World Data Bank. For checking hypothesis, the 2SLS method was chosen. The analysed period 2002-2018 years. The empirical findings proved that political stability had a negative statistically significant impact at level $1 \%$ on agriculture value-added, agricultural raw materials exports, food imports. Besides, the rule of law had a negative significant impact on the indicators: agricultural raw materials exports, value-added, and agriculture value-added. The finding proved that political and institutional imbalance restricts the recovering of the country's economic security. In this case, the government should consider not only economic parameters but also marketing and institutional during developing the mechanism to increase the level of the country's economic security.
\end{abstract}

Keywords: economic security, corruption, stability, government, brand.

Introduction. The previous financial bubble in 2007-2008 years provoked the corresponding financial crisis which had an impact on all economic sectors. Thus, the huge range of companies, banks, institutions could not pay for their financial liabilities which lead to bankruptcy. In this case, consequently, a lot of employees lost the job. At the same time, crisis provokes the outflow of foreign direct investment from the developing countries and decreasing the macroeconomic stability. Such a range of negative evidence

Cite as: Harust, Yu., Melnyk, V. Palienko, M., Prasol, L. (2019). Economic Security of the Country: Marketing, Institutional and Political Determinants. Marketing and Management of Innovations, 4, 373-382. http://doi.org/10.21272/mmi.2019.4-29 
Yu. Harust, V. Melnyk, M. Palienko, L. Prasol. Economic Security of the Country: Marketing, Institutional and Political Determinants

provokes the society's strikes around the world which negatively influenced the countries' brand.

Traditionally, the scientist as the key indicator of economic security analyses of the macroeconomic imbalance level. It should be noted, that the European Commission has changed the macroeconomic imbalance procedure after the global recession by extending the parameters of analysis and corresponding thresholds. The relevant reports involved the results of the analysis of 14 indicators which involved 28 additional indicators. These indicators estimate the internal and external characteristics of macroeconomic stability. According to the official dataset, the GDP as in the European Union as in Ukraine had declined during the crisis period (Figure 1). Thus, in Ukraine, the GDP decreased by $34,87 \%$ in 2008 compared to 2000 years. In the EU this declining was 10,64\%. Besides, in 2008 the decreasing of foreign direct investment was $53,7 \%$ in the European Union and in Ukraine - 31,6\% (Figure 2).
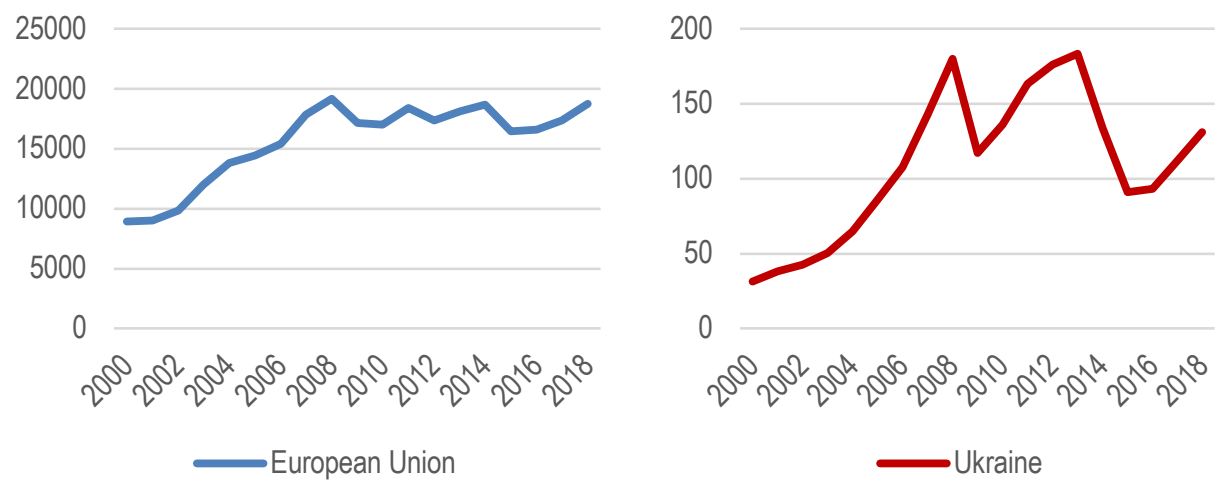

Figure 1. Dynamic of GDP in the European Union and Ukraine during 2000-2018 years, billion USD

Source: World Development Indicators, 2019.

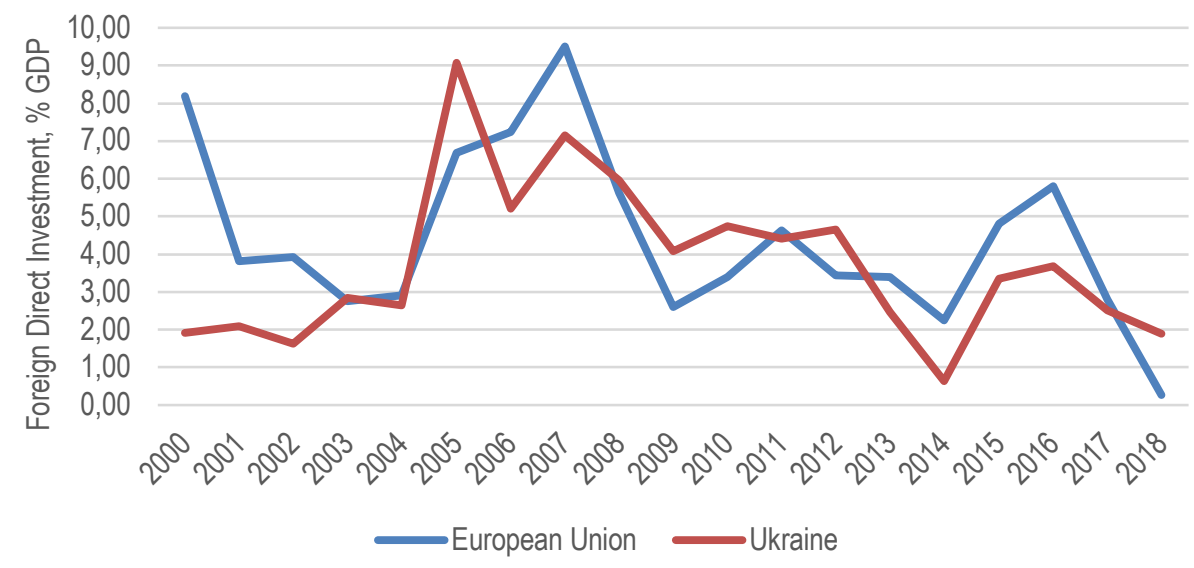

Figure 2. Dynamic of Foreign Direct Investment in the European Union and Ukraine during 2000Source: World Development Indicators, 2019. 
Noted, that range of the scientists proved that macroeconomic stability relates from the level of corruption, unemployment, social security, country's barn etc. Thus, the increasing of economic security is complex issues which contribute to analyse not only of the economic parameters, but other factors as characterized the political, institutional and marketing indicators.

Literature Review. Noted, that authors in the paper (Rejda, 2015) analysed the relationship between social insurance and economic security. For that purpose, Rejda allocated two groups of the indicators: general (loss of income, additional expenses, insufficient income and uncertainty of income); social (premature death of the family head, old age, poor health, unemployment, substandard wage, inflation, natural disasters, children born outside of marriage, personal factors).

Brück (2004) highlighted that key indicators of economic security were government policy, freedom and openness of trade. The author proved, that the government should support international cooperation and use the synchronised mechanism to achieve economic security.

The range of the authors Forrest J. Y. L., Ying Y., Gong Z., Schimmel K., Liu S., Nicholls J. and Nechval N.A. in the paper (Forrrest et al, 2018) proved that volume the foreign direct investment ha ad positive statistically significant impact on the level of country's economic security.

The same hypothesis tried to prove the scientist in the paper (Nhung, 2018) on the example of Vietnam. The authors in the paper (Ohotina et al., 2018) analysed the social and economic security of the region using the investment climate, innovations and infrastructure as the key parameters.

Besides, for that purpose the cauterization was used by the authors. A as conclusion, the authors developed the stage for increasing the level of economic security which involved: increasing of trade openness through liberalization; improving infrastructure (road, transport, logistic, etc.) with the purpose to attract tourists and additional capital; providing free movement of people.

Shvaiba (2018) proposed to estimate the social and economic security using GDP and unemployment rate as the key indicators. Besides, Shvaiba D. proposed to use the hierarchical system for analysing. The scientists in the paper (Garth et al., 2019) using the fixed regression analysis and survey analysed the significate impact of the indicators (income, mental and physical health, wealth) on the level of economic security. Odehnal J. and Neubauer J. (2018) proved the relationship between political stability and economic security using the panel model on the example of NATO countries. Noted, that Odehnal, J. and Neubauer J. analysed two group of the indicators: economic (risk of budget balance, risk of foreign debt, risk of inflation, risk of GDP per capita, risk of GDP growth, and a control variable, risk of current account as a percentage of GDP); political (terrorism, cross border conflict, ethnic tension, and foreign pressures). Singh R. and Sehrawat P. (2019) proved that the country's brand influence on economic growth and security. The results of the analysis showed that a huge range of scientists has been investigating the issues of economic security. At the same time, the unified approach to measure the relationship between key indicators and economic security has not accepted by the world scientific community. In this case, the aim of the paper is the analysis of the relationship between three group of indicators which explain the main directions of countries activities to increase the level of economic security: political, institutional and marketing. Thus, the main hypothesis of the investigation was:

$\mathrm{H} 1$ : political stability has a statistically significant impact on the country's economic security.

$\mathrm{H} 2$ : institutional parameters have a statistically significant impact on the country's economic security.

$\mathrm{H} 3$ : marketing parameters has a statistically significant impact on the country's economic security.

Methodology and research methods. The findings of the papers (Lyulyov et al., 2018; Bilan et al., 2019a; Bilan et al., 2019b; Bilan et al., 2019c; Milova et al., 2019) empirical proved that social, cultural, political, institutional and marketing determinants in the different combination could significantly increase or decrease the macroeconomic stability of the national economy. In this case, the relationship of the economic security parameters could be explained as functional relation: 
Yu. Harust, V. Melnyk, M. Palienko, L. Prasol. Economic Security of the Country: Marketing, Institutional and Political Determinants

$$
\text { ESit }=f\left(\text { Politica }_{t}, \text { Institutional }_{t}, \text { Marketing }_{t}\right)
$$

where ES - i-elements of economic security in t period; Politicalt - political parameters in t period; Institutionalt, - institutional parameters in t period; Marketingt - country's brand in t period.

The assessment of economic security level based on the estimation of the dynamic of the macroeconomic parameters. Agreed with the assumption of V. P. Kapysh (2016), that economic security could be estimated by the criteria as follows: industry development level; agribusiness development level; employment and unemployment level; trade openness; the economy's dependence on natural resources. Besides, considering the findings of T.P. Yapatake Kossele and L.J. Shan (2018), the following indicators were proposed to consider:

- adjusted net national income per capita (ANI);

- $\quad$ agricultural raw materials exports (ARM);

- $\quad$ agriculture, value-added (AVA);

- external balance on goods and services (EGBS);

- $\quad$ food exports (FEX); food imports (FIM);

- $\quad$ foreign direct investment, nett inflows (FDI);

- $\quad$ GDP growth (GR);

- $\quad$ wage and salaried workers, total (WSB);

- $\quad$ GDP per capita growth (GPC);

- industry, value added (IVA);

- $\quad$ total natural resources rents (NRS);

- $\quad$ trade (TRAD).

After dividing each side of Eq. (1) the modified model can be shown as in Equations (2-27):

$$
\begin{aligned}
& A N I_{1 t}=a_{1}+\beta_{1} P S_{t}+\beta_{2} \operatorname{Corr}_{t}+\beta_{3} R L_{t}+\beta_{4} \text { Brand }_{t}+\varepsilon_{t} \\
& A N I_{2 t}=a_{1}+\beta_{1} V A_{t}+\beta_{2} \operatorname{Corr}_{t}+\beta_{3} R L_{t}+\beta_{4} \text { Brand }_{t}+\varepsilon_{t} \\
& A R M_{1 t}=a_{1}+\beta_{1} P S_{t}+\beta_{2} \operatorname{Corr}_{t}+\beta_{3} R L_{t}+\beta_{4} \text { Brand }_{t}+\varepsilon_{t} \\
& A R M_{2 t}=a_{1}+\beta_{1} V A_{t}+\beta_{2} \operatorname{Corr}_{t}+\beta_{3} R L_{t}+\beta_{4} \text { Brand }_{t}+\varepsilon_{t} \\
& A V A_{1 t}=a_{1}+\beta_{1} P S_{t}+\beta_{2} \operatorname{Corr}_{t}+\beta_{3} R L_{t}+\beta_{4} \text { Brand }_{t}+\varepsilon_{t} \\
& A V A_{2 t}=a_{1}+\beta_{1} V A_{t}+\beta_{2} \operatorname{Corr}_{t}+\beta_{3} R L_{t}+\beta_{4} \text { Brand }_{t}+\varepsilon_{t} \\
& E G B S_{1 t}=a_{1}+\beta_{1} P S_{t}+\beta_{2} \operatorname{Corr}_{t}+\beta_{3} R L_{t}+\beta_{4} \text { Brand }_{t}+\varepsilon_{t} \\
& E G B S_{2 t}=a_{1}+\beta_{1} V A_{t}+\beta_{2} \operatorname{Corr}_{t}+\beta_{3} R L_{t}+\beta_{4} \text { Brand }_{t}+\varepsilon_{t} \\
& F E X_{1 t}=a_{1}+\beta_{1} P S_{t}+\beta_{2} \operatorname{Corr}_{t}+\beta_{3} R L_{t}+\beta_{4} \text { Brand }_{t}+\varepsilon_{t} \\
& F E X_{2 t}=a_{1}+\beta_{1} V A_{t}+\beta_{2} \operatorname{Corr}_{t}+\beta_{3} R L_{t}+\beta_{4} \text { Brand }_{t}+\varepsilon_{t} \\
& \text { FIM }_{1 t}=a_{1}+\beta_{1} P S_{t}+\beta_{2} \operatorname{Corr}_{t}+\beta_{3} R L_{t}+\beta_{4} \text { Brand }_{t}+\varepsilon_{t} \\
& F I M_{2 t}=a_{1}+\beta_{1} V A_{t}+\beta_{2} \operatorname{Corr}_{t}+\beta_{3} R L_{t}+\beta_{4} \text { Brand }_{t}+\varepsilon_{t} \\
& F D I_{1 t}=a_{1}+\beta_{1} P S_{t}+\beta_{2} \operatorname{Corr}_{t}+\beta_{3} R L_{t}+\beta_{4} \text { Brand }_{t}+\varepsilon_{t} \\
& F D I_{2 t}=a_{1}+\beta_{1} V A_{t}+\beta_{2} \operatorname{Corr}_{t}+\beta_{3} R L_{t}+\beta_{4} \text { Brand }_{t}+\varepsilon_{t}
\end{aligned}
$$




$$
\begin{aligned}
& G R_{1 t}=a_{1}+\beta_{1} P S_{t}+\beta_{2} \operatorname{Corr}_{t}+\beta_{3} R L_{t}+\beta_{4} \text { Brand }_{t}+\varepsilon_{t} \\
& G R_{2 t}=a_{1}+\beta_{1} V A_{t}+\beta_{2} \operatorname{Corr}_{t}+\beta_{3} R L_{t}+\beta_{4} \text { Brand }_{t}+\varepsilon_{t} \\
& G P C_{1 t}=a_{1}+\beta_{1} P S_{t}+\beta_{2} \operatorname{Corr}_{t}+\beta_{3} R L_{t}+\beta_{4} \text { Brand }_{t}+\varepsilon_{t} \\
& G P C_{2 t}=a_{1}+\beta_{1} V_{t}+\beta_{2} \operatorname{Corr}_{t}+\beta_{3} R L_{t}+\beta_{4} \text { Brand }_{t}+\varepsilon_{t} \\
& W S B_{1 t}=a_{1}+\beta_{1} P S_{t}+\beta_{2} \operatorname{Corr}_{t}+\beta_{3} R L_{t}+\beta_{4} \text { Brand }_{t}+\varepsilon_{t} \\
& W S B_{2 t}=a_{1}+\beta_{1} V A_{t}+\beta_{2} \operatorname{Corr}_{t}+\beta_{3} R L_{t}+\beta_{4} \text { Brand }_{t}+\varepsilon_{t} \\
& I V A_{1 t}=a_{1}+\beta_{1} P S_{t}+\beta_{2} \operatorname{Corr}_{t}+\beta_{3} R L_{t}+\beta_{4} \text { Brand }_{t}+\varepsilon_{t} \\
& I V A_{2 t}=a_{1}+\beta_{1} V A_{t}+\beta_{2} \operatorname{Corr}_{t}+\beta_{3} R L_{t}+\beta_{4} \text { Brand }_{t}+\varepsilon_{t} \\
& N R S_{1 t}=a_{1}+\beta_{1} P S_{t}+\beta_{2} \operatorname{Corr}_{t}+\beta_{3} R L_{t}+\beta_{4} \text { Brand }_{t}+\varepsilon_{t} \\
& N R S_{2 t}=a_{1}+\beta_{1} V A_{t}+\beta_{2} \operatorname{Corr}_{t}+\beta_{3} R L_{t}+\beta_{4} \text { Brand }_{t}+\varepsilon_{t} \\
& T R A D_{1 t}=a_{1}+\beta_{1} P S_{t}+\beta_{2} \operatorname{Corr}_{t}+\beta_{3} R L_{t}+\beta_{4} \text { Brand }_{t}+\varepsilon_{t} \\
& T R A D_{2 t}=a_{1}+\beta_{1} V A_{t}+\beta_{2} \operatorname{Corr}_{t}+\beta_{3} R L_{t}+\beta_{4} \text { Brand }_{t}+\varepsilon_{t}
\end{aligned}
$$

where political and institutional parameters were collected from the Worldwide Governance Indicators (2019). The finding in the paper Bilan et al. (2019a) on investigating the impact of Public governance efficiency on macroeconomic stability in Ukraine proved the statistical significance impact at levels 1-5\% political stability and absence of violence/terrorism (PS); voice and accountability rating (VA); rule of law (RL); control of corruption (Corr); Brand - country's brand was calculated using by the methodology in the paper Lyulyov et al. (2018).

The descriptive statistics of the main indicators of economic security of the countries in the period 2002-2018 showed in Table 1. The data on ANI (current US\$), ARM ( $\%$ of merchandise exports), AVA ( $\%$ of GDP), EGBS (\% of GDP), FEX (\% of merchandise exports), FIM ( $\%$ of merchandise imports), FDI ( $\%$ of GDP), GR (annual \%), WSB (\% of total employment), GPC (annual \%), IVA (annual \% growth), NRS (\% of GDP) and TRAD (\% of GDP) were taken from the World Bank's "World Development Indicators" (2019).

Table 1. Summary statistics, 2002-2018

\begin{tabular}{cccccccccccccc}
\hline & ANI & ARM & AVA & EGBS & FEX & FIM & FDI & GR & WSB & GPC & IVA & NRS & TRAD \\
\hline Maximum & 3348.9 & 2.1 & 12.9 & 6.73 & 41.9 & 10.78 & 9.1 & 12.11 & 84.36 & 12.9 & 11.25 & 10.04 & 113.77 \\
Minimum & 701.43 & .9 & 6.54 & -9.23 & 10.4 & 6.37 & .63 & -14.7 & 80.7 & - & -19.4 & 3.61 & 89.86 \\
& & & & & & & & & & 14.4 & & & \\
Mean & 2155.3 & 1.5 & 9.31 & -3.78 & 23.11 & 8.37 & 3.9 & 1.99 & 82.26 & 2.83 & -.078 & 6.27 & 100.5 \\
$\begin{array}{c}\text { Standard } \\
\text { deviation }\end{array}$ & 838.8 & .4 & 1.96 & 4.69 & 11.33 & 1.47 & 2.1 & 6.84 & 1.35 & 6.69 & 9.08 & 2.14 & 6.65 \\
$\begin{array}{c}\text { Coefficient } \\
\text { of variation }\end{array}$ & 0.39 & 0.3 & 0.21 & -1.24 & 0.49 & 0.18 & 0.5 & 3.44 & 0.02 & 2.36 & -116 & 0.34 & 0.07 \\
\hline
\end{tabular}

Source: developed by authors.

The largest variation data (more 33\%) of the average meaning had the in the analysed period had more than half of indicators of Ukrainian economic security (ANI, EGBS, FEX, FDI, GR, GPC, IVA, TRAD). It means that dataset was heterogeneity which provoke the difficulties in forecasting data for the future analysis. Homogeneous, that is, all values of the data were equal throughout the study period. The indicators WSB and TRAD were homogeneous (all values of the data were equal throughout the study period). 
Yu. Harust, V. Melnyk, M. Palienko, L. Prasol. Economic Security of the Country: Marketing, Institutional and Political Determinants
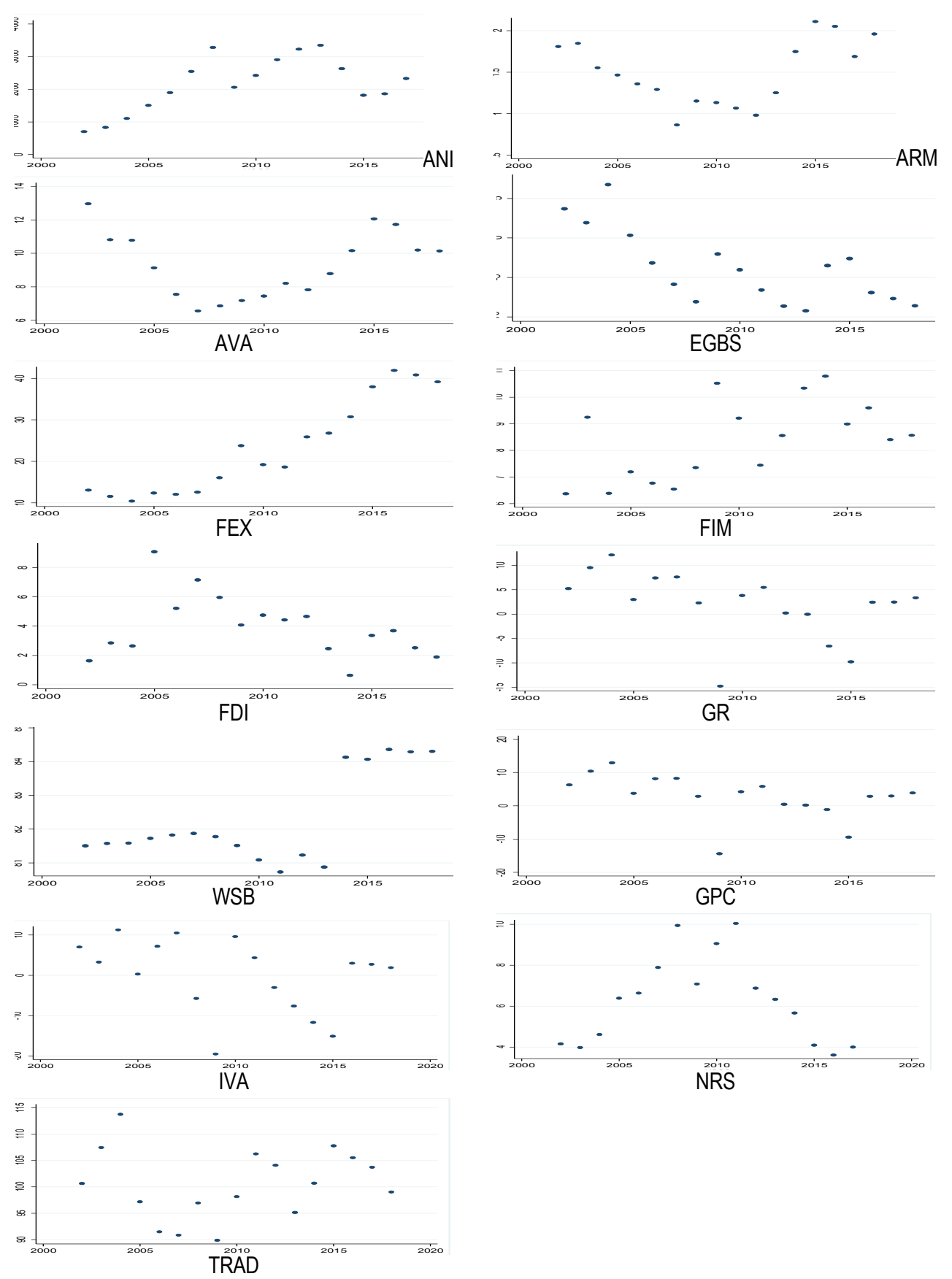

Figure 3. Evolution of Ukrainian economic securities parameters, 2002-2018 years Source: developed by authors. 
Yu. Harust, V. Melnyk, M. Palienko, L. Prasol. Economic Security of the Country: Marketing, Institutional and Political Determinants

Segmentation of variation indicators all series of economic security indicators could be divided into three main groups: with weakly variable (Coefficient of variation $\leq 10 \%$ ) - WSB ,TRAD; with average variable $(10 \%<$ Coefficient of variation $\leq 33 \%)-A R M$, AVA, FIM; with strong variable Coefficient of variation $>33 \%$ ) - ANI, EGBS, FEX, FDI, GR, GPC, IVA, TRAD.

As illustrated in Figure 3 indicators EGBS and FDI, GR and IVA have followed a constant trend in the considered period. However, despite the homogeneous characters of indicators WSB and TRAD their tendencies illustrated different phases of evolution during the period from 1980 to 2012.

All indicators of economic security were in the third segment which justified using procedure calculates the two-stage least squares (2SLS) for solving the equitation (2)-(27). The authors in the paper (MaydeuOlivares et al., 2019) identified, that for abovementioned methods the following was characterized by: "Coverage rates of the causal effect using regression methods are always unacceptably low (often 0)». The 2SLS model is comprised of the following two linear regression models:

$$
\left\{\begin{array}{c}
y=X_{e x} \beta_{e x}+V_{e n} \beta_{e n}+e=X \beta+e \\
V_{e n}=X_{e x} \Gamma_{e x}+X_{i v} \Gamma_{i v}+E=Z \Gamma+\mathrm{E}
\end{array}\right.
$$

where $\boldsymbol{y}$ - vector dependent variable; $\mathrm{X}_{\mathrm{ex}}$ - matrix of exogenous regressor variables; $\mathrm{X}_{\mathrm{iv}}$ - matrix of instrumental variables; $V_{\mathrm{en}}$ - matrix of endogenous regressor variables; $\mathrm{e}, \mathrm{E}$ - terms of errors; $\Gamma_{\mathrm{ex}}, \Gamma_{\mathrm{iv}}-$ matrix of parameters.

Results. The results from 2SLS modelling for strong variable indicators of economic security of the national economy showed in Table 2 and 3 . The most significant impact of political, institutional, marketing parameters for the indicators: $\mathrm{FEX}\left(\mathrm{R}^{2}=0,78\right)$ and $\mathrm{FDI}\left(\mathrm{R}^{2}=0,66\right)$. For the most equations $\mathrm{PS}$ had the direct, however, statistically non-significant impact, excluding indicators FEX, FDI and NRS (the statistical significance impact at level 1-5\%).

Table 2. Results from 2SLS modelling for ANI, EGBS, FEX, FDI and PS, Corr, VA, RL, Brand

\begin{tabular}{|c|c|c|c|c|c|c|c|c|c|c|c|c|c|}
\hline \multirow{2}{*}{\multicolumn{2}{|c|}{ Variable }} & \multicolumn{4}{|c|}{ Coefficient } & \multicolumn{4}{|c|}{ t-statistic } & \multicolumn{4}{|c|}{ Prob. } \\
\hline & & ANI & EGBS & FEX & FDI & ANI & EGBS & FEX & FDI & ANI & EGBS & FEX & FDI \\
\hline \multirow{6}{*}{$\begin{array}{l}\frac{\overline{0}}{\overline{0}} \\
\frac{0}{2}\end{array}$} & PS & 14.09 & 1.06 & -1.8 & 1.61 & 0.05 & 0.74 & -6.7 & 3.86 & 0.6 & 0.48 & 0.00 & 0.00 \\
\hline & Corr & -29.9 & 8.85 & -18.9 & 10.25 & -1.5 & 0.79 & -1.4 & 3.18 & 0.16 & 0.45 & 0.18 & 0.00 \\
\hline & $\mathrm{RL}$ & 95.98 & -46.8 & 52.1 & -6.8 & 1.45 & -1.32 & 1.22 & -0.6 & 0.17 & 0.21 & 0.25 & 0.51 \\
\hline & Brand & 67.95 & -30.9 & 37.27 & 9.35 & 1.54 & -1.31 & 1.31 & 1.38 & 0.15 & 0.211 & 0.21 & 0.19 \\
\hline & $\mathrm{R}^{2}$ & 0.19 & 0.15 & 0.78 & 0.66 & & & & & & & & \\
\hline & Adj $R^{2}$ & -0.01 & -0.04 & 0.73 & 0.57 & & & & & & & & \\
\hline \multirow{6}{*}{$\begin{array}{l}\frac{N}{\Phi} \\
\frac{0}{2} \\
\frac{0}{2}\end{array}$} & VA & 22.41 & -14.6 & 22.54 & 1.58 & 3.12 & -3.77 & 1.78 & 0.7 & 0.09 & 0.00 & 0.09 & 0.497 \\
\hline & Corr & -38.8 & 13.9 & -22.7 & 9.00 & -2.6 & 1.74 & -0.8 & 1.91 & 0.02 & 0.11 & 0.40 & 0.078 \\
\hline & $\mathrm{RL}$ & 62.67 & -23.9 & 25.73 & -10.8 & 1.25 & -0.93 & 0.30 & -0.7 & 0.24 & 0.37 & 0.76 & 0.48 \\
\hline & Brand & 37.79 & -11.6 & 26.61 & 4.23 & 1.11 & -0.67 & 0.45 & 0.41 & 0.29 & 0.51 & 0.66 & 0.68 \\
\hline & $\mathrm{R}^{2}$ & 0.55 & 0.57 & 0.22 & & & & & & & & & \\
\hline & Adj $R^{2}$ & 0.44 & 0.48 & 0.04 & & & & & & & & & \\
\hline
\end{tabular}

Source: developed by authors.

The findings of modelling (Table 2) proved, that achieving the political stability in the country ha ad more powerful impact on increasing of economic security in Ukraine than institutional and country's brand factors. Considering the finding at the first stage the government should pay attention to developing the mechanism to overcome corruption in the country.

Based on the descriptive characteristics of the institutional, political and marketing determinants the most relevant were political and institutional indicators for the point of view to achieve economic security. 
Yu. Harust, V. Melnyk, M. Palienko, L. Prasol. Economic Security of the Country: Marketing, Institutional and Political Determinants

Table 3. Results from 2SLS modelling for GR, EGBS, FEX, FDI and PS, VA, Corr, RL, Brand

\begin{tabular}{|c|c|c|c|c|c|c|c|c|c|c|c|c|c|}
\hline \multirow{2}{*}{\multicolumn{2}{|c|}{ Variable }} & \multicolumn{4}{|c|}{ Coefficient } & \multicolumn{4}{|c|}{ t-statistic } & \multicolumn{4}{|c|}{ Prob. } \\
\hline & & GR & GPC & IVA & NRS & GR & GPC & IVA & NRS & GR & GPC & IVA & NRS \\
\hline \multirow{6}{*}{$\begin{array}{l}\frac{\bar{d}}{\mathrm{D}} \\
\frac{0}{2}\end{array}$} & PS & 3.4 & 2.88 & 4.15 & 1.68 & 1.76 & 1.48 & 1.61 & 2.94 & 0.10 & 0.16 & 0.13 & 0.01 \\
\hline & Corr & 22.7 & 22.5 & 33.7 & -3.1 & 1.52 & 1.5 & 1.69 & -0.7 & 0.15 & 0.15 & 0.11 & 0.47 \\
\hline & $\mathrm{RL}$ & -14.5 & -18.5 & -40 & 10.2 & -0.3 & -0.3 & -0.6 & 0.73 & 0.76 & 0.70 & 0.53 & 0.47 \\
\hline & Brand & 14.37 & 11.59 & 2.93 & 12.4 & 0.46 & 0.37 & 0.07 & 1.33 & 0.65 & 0.72 & 0.94 & 0.21 \\
\hline & $\mathrm{R}^{2}$ & 0.29 & 0.25 & 0.28 & 0.45 & & & & & & & & \\
\hline & Adj $R^{2}$ & 0.13 & 0.07 & 0.12 & 0.31 & & & & & & & & \\
\hline \multirow{6}{*}{$\begin{array}{l}\frac{N}{0} \\
\frac{0}{2}\end{array}$} & VA & -17.6 & $\begin{array}{l}-17.8 \\
\end{array}$ & -15 & $\overline{4.3}$ & -2.7 & -2.8 & -1.6 & 1.87 & 0.018 & 0.01 & 0.12 & 0.08 \\
\hline & Corr & 28.10 & 28.21 & 38.07 & -5.9 & 2.08 & 2.18 & 1.89 & -1.2 & 0.06 & 0.04 & 0.08 & 0.24 \\
\hline & $\mathrm{RL}$ & 11.32 & 8.08 & -18.1 & 7.2 & 0.26 & 0.19 & -0.3 & 0.44 & 0.79 & 0.85 & 0.78 & 0.66 \\
\hline & Brand & 33.87 & 32.29 & 18.63 & 7.1 & 1.16 & 1.15 & 0.43 & 0.64 & 0.26 & 0.27 & 0.67 & 0.53 \\
\hline & $\mathrm{R}^{2}$ & 0.44 & 0.46 & 0.29 & & & & & & & & & \\
\hline & Adj $R^{2}$ & 0.31 & 0.33 & 0.12 & & & & & & & & & \\
\hline
\end{tabular}

Source: developed by authors.

At the same time, for the weak variable indicators the key role had the marketing factors with huge statistical significance. Thus, the increasing of country's brand by one point provoke to increasing of WSB by 8.6-point, TRAD by 7.5 points, Table 4-5.

Table 4. Results from 2SLS modelling for AVA, ARM, FIM and PS, VA, Corr, RL, Brand

\begin{tabular}{|c|c|c|c|c|c|c|c|c|c|c|}
\hline \multirow{2}{*}{\multicolumn{2}{|c|}{ Variable }} & \multicolumn{3}{|c|}{ Coefficient } & \multicolumn{3}{|c|}{ t-statistic } & \multicolumn{3}{|c|}{ Prob. } \\
\hline & & AVA & ARM & FIM & AVA & ARM & FIM & AVA & ARM & FIM \\
\hline \multirow{6}{*}{$\begin{array}{l}\overline{\bar{d}} \\
\overline{\frac{0}{2}}\end{array}$} & PS & -1.5 & -0.35 & -0.94 & -3.21 & -4.8 & -2.61 & 0.00 & 0.00 & 0.02 \\
\hline & Corr & 0.97 & 1.00 & -5.73 & 0.26 & 1.75 & -2.04 & 0.79 & 0.104 & 0.06 \\
\hline & $\mathrm{RL}$ & -16.4 & -3.32 & 1.79 & -1.42 & -1.79 & 0.20 & 0.18 & 0.09 & 0.84 \\
\hline & Brand & -3.53 & 0.32 & 3.76 & -0.46 & -0.27 & 0.64 & 0.65 & 0.79 & 0.53 \\
\hline & $R^{2}$ & 0.48 & 0.68 & 0.46 & & & & & & \\
\hline & Adj $R^{2}$ & 0.36 & 0.61 & 0.33 & & & & & & \\
\hline \multirow{6}{*}{$\begin{array}{l}\frac{N}{\Phi} \\
\frac{0}{2}\end{array}$} & $\overline{V A}$ & -4.16 & -0.42 & 2.32 & -1.97 & -0.93 & 1.48 & 0.07 & 0.37 & 0.16 \\
\hline & Corr & 3.17 & 1.31 & -6.23 & 0.72 & 1.39 & -1.91 & 0.48 & 0.18 & 0.07 \\
\hline & $\mathrm{RL}$ & -8.31 & -2.23 & -1.16 & -0.59 & -0.74 & -0.11 & 0.56 & 0.47 & 0.91 \\
\hline & Brand & 5.15 & 0.91 & 2.07 & 0.54 & 0.45 & 0.29 & 0.597 & 0.66 & 0.77 \\
\hline & $\mathrm{R}^{2}$ & 0.28 & 0.16 & 0.29 & & & & & & \\
\hline & Adj $R^{2}$ & 0.11 & -0.02 & 0.13 & & & & & & \\
\hline
\end{tabular}

Source: developed by authors.

Noted, the positive impact of country's brand on the economic security could be justified by that the Ukrainian government had implemented the efficient instrument for stabilization of economic process in the countries (WSB, TRAD).

Table 5. Results from 2SLS modelling for WSB, TRAD and PS, VA, Corr, RL, Brand

\begin{tabular}{|c|c|c|c|c|c|c|c|}
\hline & \multirow{2}{*}{ Variable } & \multicolumn{2}{|c|}{ Coefficient } & \multicolumn{2}{|c|}{ t-statistic } & \multicolumn{2}{|c|}{ Prob. } \\
\hline & & WSB & TRAD & WSB & TRAD & WSB & TRAD \\
\hline & 1 & 2 & 3 & 4 & 5 & 6 & 7 \\
\hline \multirow{5}{*}{$\begin{array}{l}\frac{\sigma}{\Phi} \\
\frac{0}{0} \\
\sum\end{array}$} & PS & 1.43 & -2.89 & -13.16 & -1.42 & 0.00 & 0.17 \\
\hline & Corr & 2.69 & -5.81 & 3.19 & -0.37 & 0.00 & 0.72 \\
\hline & $\mathrm{RL}$ & 3.53 & 23.41 & 1.32 & -0.47 & 0.21 & 0.65 \\
\hline & Brand & 8.6 & 7.50 & 4.88 & 2.27 & 0.00 & 0.04 \\
\hline & $\mathrm{R}^{2}$ & 0.94 & 0.16 & & & & \\
\hline
\end{tabular}


Yu. Harust, V. Melnyk, M. Palienko, L. Prasol. Economic Security of the Country: Marketing, Institutional and Political Determinants

\begin{tabular}{|c|c|c|c|c|c|c|c|}
\hline & & & & & & \multicolumn{2}{|c|}{ Continued Table 5} \\
\hline & 1 & 2 & 3 & 4 & 5 & 6 & 7 \\
\hline & Adj $R^{2}$ & 0.92 & -0.02 & & & & \\
\hline \multirow{6}{*}{$\begin{array}{l}\frac{N}{\Phi} \\
\frac{0}{2}\end{array}$} & VA & 1.35 & -16.56 & 0.89 & -2.39 & 0.38 & 0.03 \\
\hline & Corr & 2.76 & 1.67 & 0.88 & 0.12 & 0.39 & 0.91 \\
\hline & $\mathrm{RL}$ & 2.58 & 6.15 & 0.26 & 0.13 & 0.80 & 0.89 \\
\hline & Brand & 8.71 & 10.4 & 1.27 & 3.34 & 0.00 & 0.00 \\
\hline & $\mathrm{R}^{2}$ & 0.21 & 0.33 & & & & \\
\hline & Adj R2 & 0.03 & 0.17 & & & & \\
\hline
\end{tabular}

Source: developed by authors.

In Table 4 PS had a negative and statistically significant impact at level $1 \%$ on AVA, ARM, FIM, as the impact of RL were significant for indicators ARM, VA and AVA but negative. In Table 5 impact of corruption was a significant impact at level $1 \%$ on WSB, but negative on TRAD, as RL in both regressions' the positive impact on WSB and TRAD, however that impact was non-significant.

Conclusions. It should be noted, that obtained results were correlated with findings in the paper Bilan et al. (2019a) and proved that political and institutional imbalance restricts the recovering of the country's economic security. Noted, that the reforms and mechanisms for increasing of economic security level should be complex and considering all directions of economic activities in the country which allow receiving the synergy effect. Considering abovementioned findings and climate in Ukraine, at the first stage the, Ukrainian government should overcome the issues with political stability.

Author Contributions: conceptualization, methodology, software, validation, writing-original draft preparation, visualization - Y.H., V.M., L.P., M.P.

\section{References}

Bilan, Y., Lyeonov, S., Lyulyov, O., \& Pimonenko, T. (2019c). Brand management and macroeconomic stability of the country [Zarzadzanie marka i stabilność makroekonomiczna kraju]Polish Journal of Management Studies, 19(2), 61-74. doi:10.17512/pjms.2019.19.2.05

Bilan, Y., Raišienè, A. G., Vasilyeva, T., Lyulyov, O., \& Pimonenko, T. (2019a). Public governance efficiency and macroeconomic stability: Examining convergence of social and political determinants. Public Policy and Administration, 18(2), 241-255. doi:10.13165/VPA-19-18-2-05

Bilan, Y., Vasilyeva, T., Lyulyov, O., \& Pimonenko, T. (2019b). EU vector of ukraine development: Linking between macroeconomic stability and social progress. International Journal of Business and Society, 20(2), 433-450

Brück, T. (2004). An Economic Analysis of Security Policies, DIWDiskussionspapiere, No. 456. Retrieved from: http://hdl.handle.net/10419/18308

Forrest, J. Y. L., Ying, Y., Gong, Z., Schimmel, K., Liu, S., Nicholls, J., \& Nechval, N. A. (2018). Economic Security Under Disturbances of Foreign Capital. In Currency Wars, pp. 197-215.

Garth E. Kendall, Ha Nguyen \& Rachel Ong. (2019). The association between income, wealth, economic security perception, and health: a longitudinal Australian study. Health Sociology Review, 28:1, 20-38, DOI: 10.1080/14461242.2018.1530574

Kapysh, V.P. (2016). The evolution of theoretical approaches to the interpretation of the category of "economic security". Policy and Law, 1, 56-61.

Lyulyov, O., Chygryn, O., and Pimonenko, T. (2018). National Brand as a Marketing Determinant of Macroeconomic Stability. Marketing and Management of Innovations, 3, 142-152. http://doi.org/10.21272/mmi.2018.3-12

Maydeu-Olivares, A., Shi, D., \& Rosseel, Y. (2019). Instrumental variables two-stage least squares (2SLS) vs. maximum likelihood structural equation modeling of causal effects in linear regression models. Structural Equation Modeling: A Multidisciplinary Journal, 1-17.

Milova, T., Troshkina, K., Horlov, Y. \& Dobkowski, J. (2019). Country's Brand and Corruption Level: Cointegration Analysis. Marketing and Management of Innovations, 3, 366-373. http://doi.org/10.21272/mmi.2019.3-28

Nhung, V. T. (2018). The Foreign Direct Investment (FDI) of Korea in Vietnam from the Perspective of Economic Security. VNU Journal of Science: Economics and Business, 34(3).

Odehnal, J., \& Neubauer, J. (2018). Economic, Security, and Political Determinants of Military Spending in NATO Countries. Defence and Peace Economics, 1-15. 
Yu. Harust, V. Melnyk, M. Palienko, L. Prasol. Economic Security of the Country: Marketing, Institutional and Political Determinants

Ohotina, A., Lavrinenko, O., Ignatjeva, S., \& Lonska, J. (2018). Socio-economic security as a determinant of regional differences in the investment climate in the region. Journal of Security \& Sustainability Issues, 7(3).

Rejda, G. E. (2015). Social insurance and economic security. Routledge.

Shvaiba, D. (2018). Socio-Economic Security of the Hierarchical System. Bulletin of Science and Practice, T. 4, No. 6, 248-254

Singh, R., \& Sehrawat, P. (2019). Integrative Global Branding, Competitive Approach for Economic Growth and Positioning of Products. Competitive Approach for Economic Growth and Positioning of Products.

World Data Bank. Worldwide Governance Indicators. Available online: https://datacatalog.worldbank.org/dataset/worldwide-governanceindicators (accessed on 1 June 2019)

Yapatake Kossele, T.P., \& Shan, L. J. (2018). Economic Security and the Political Governance Crisis in Central African Republic. African Development Review, 30(4), 462-477.

Юрій Гаруст, д.ю.н., дочент, Сумський державний університет (Україна);

Вадим Мельник, к.ю.н., Сумський державний університет (Україна);

Максим Палієнко, Ph.D., Університет Інсурбіа (Iталія);

Леся Прасол, підприємець (Китай).

Економічна безпека країни: маркетингові, інституційні та політичні детермінанти

Метою статті $є$ аналіз основних показників, які впливають на рівень економічної безпеки країни Авторами проаналізовано основні підходи до визначення економічної безпеки. Встановлено, що традиційно економічну безпеку досліджували з точки зори оцінювання економічних параметрів розвитку країни. У роботі обгрунтовано, що політичні, інституціональні, маркетингові фрактори в різних комбінаціях можуть суттєво підсилити, так і зменшити поточний рівень макроекономічних показників національної економіки. На основі аналізу наукової літератури, авторами запропоновано виокремити три групи показників, що впливають на рівень економічної безпеки країни, а саме: маркетингові, політичні та інституційні. До політичних показників включено такі параметри як: насильство/тероризм; свобода слова; верховенство права; контроль корупції. Маркетингова група показників містила параметри, що оцінюють бренд країни. Інституційна група включає: скоригований чистий національний доходів на душу населення; експорт сільськогосподарської сировини; додана вартість сільського господарства; зовнішній баланс товарів і послуе; експорт продовольства; імпорт продовольства; прямі іноземні інвестиції, зростання ВВП; заробітна плата; зростання ВВП на душу населення; додана вартість промисловості; загальна орендна плата за природні ресурси; торгівля. У статті, авторами висунуто гіпотезу про наявність статистично значущого впливу маркетингових, політичних та інституційних параметрів на рівень економічної безпеки країни. Інформаційну базу дослідження згенеровано з баз даних: World Government Indicators, Future Brand, World Data Bank за 2002-2018 роки. Для перевірки гіпотези обрано метод 2SLS. Емпіричні результати дали підстави зробити висновок, що політична стабільність має негативний статистично значущий вплив на рівні 1\% на додану вартість сільського господарства, експорт сільськогосподарської сировини, імпорт продовольства. Крім того, верховенство права негативно впливає на такі показники як: експорт сільськогосподарської сировини та додана вартість сільського господарства. Отримані результати засвідчили, що політичні та інституційні дисбаланси обмежують відновлення економічної безпеки в країні. У цьому випадку, уряд повинен враховувати не лише економічні параметри, а й маркетингові та інституиійні під час розроблення механізму підвищення рівня економічної безпеки країни.

Ключові слова: економічна безпека, корупція, стабільність, уряд, бренд.

Manuscript received: 26.09.2019.

(C) The author(s) 2019. This article is published with open access at Sumy State University. 